\title{
ANTIMICROBIAL POTENTIAL OF TUBER PART OF THE TRADITIONAL MEDICINAL CLIMBER, SOLENA AMPLEXICAULIS (LAM.) GANDHI. AGAINST CERTAIN HUMAN PATHOGENS
}

\author{
Krishna Moorthy Karthika* and Subramaniam Paulsamy \\ Department of Botany, Kongunadu Arts and Science College, Coimbatore - 641 029, Tamil Nadu, India \\ *Corresponding Author's Email: karthika1431989@gmail.com
}

\begin{abstract}
The present study was made to evaluate the in vitro antimicrobial activity minimum inhibitory concentration of Solena amplexicaulis tuber extracts [hexane, benzene, chloroform, methanol and water] against 15 bacterial and 9 fungal species and to determine the minimum inhibitory concentration (MIC) for its methanolic extract against the human pathogens. In vitro antimicrobial activity was determined by using agar disc diffusion technique and MIC was determined by using broth dilution method. The results of the study revealed that the chloroform extract showed highest degree of antimicrobial activity against all the microbes tested than the other extracts. The MIC exhibited by methanolic tuber extract against the tested organisms was ranging between 300 and $600 \mu \mathrm{g} / \mathrm{mL}$ for bacterial species and between 300 and $500 \mu \mathrm{g} / \mathrm{mL}$ for fungal species. $S$. amplexicaulis tuber extracts especially chloroform extract inhibits the growth of all human pathogens.

Key Words: Solena amplexicaulis, Antimicrobial activity, MIC, chloroform extract.
\end{abstract}

\section{INTRODUCTION}

Now a days the account of infectious disease is very high throughout the world. The World Health Organization (WHO) estimates that almost 50,000 people are dieing each day as of infectious diseases ${ }^{1}$. The synthetic drugs are insufficient for the treatment of diseases and highly expensive also ${ }^{2}$. In recent years, there has been a gradual revival of interest in the use of medicinal plants in developed as well as in developing countries, because plant derived drugs or novel phytochemicals have been reported to be more safe and without any side effects ${ }^{3}$. Hence, it is of interest to determine the scientific basis for the traditional uses of medicinal plants. Several works have demonstrated in laboratory trials that plant tissues, such as roots, leaves, seeds and flowers posses inhibitory properties against bacteria, fungi and insects ${ }^{4,5}$.

Solena amplexicaulis is commonly called as creeping cucumber, belongs to the family, Cucurbitaceae. The traditional healers are prescribing the tuber of this species as astringent, appetizer, carminative, caridotonic, digestive, diuretic, expectorant, invigorating, purgative, stimulant, sour and thermogenic ${ }^{6,7}$. The whole plant is said to be potential source of natural antioxidant ${ }^{8,9}$, antidiabetic agent ${ }^{10}$ and antibacterial agent ${ }^{11}$ also. It is recognized as CNS active, diuretic, febrifuge and hypothermic $^{12,7}$. Crude leaf juice is used to cure jaundice ${ }^{13}$. Raw unripe fruits are eaten to strengthen the body ${ }^{14}$. The decoction of the root is administered orally to cure stomachache ${ }^{15}$. The seeds are purgative ${ }^{7}$.

Due to this medicinal importance, the plant was taken to investigate the antimicrobial activity and minimum inhibitory concentration (MIC) of tuber extract of S. amplexicaulis against certain human pathogenic microbes.

\section{MATERIALS AND METHODS}

\section{Plant material}

The fresh tuber part of S. amplexicaulis was collected from a scrub jungle in Madukkarai, Coimbatore district, Tamil Nadu, India. The authenticity of the plant was confirmed in Botanical Survey of India, Southern Regional Centre, Coimbatore by referring the deposited specimen (Voucher specimen number: CPS 313). Collected plant materials were washed thoroughly in tap water, cut into small pieces, shade dried and then homogenized to fine powder and stored in air tight bottles.

\section{Preparation of extracts}

About $50 \mathrm{~g}$ of powdered plant materials were extracted $(50 \mathrm{~g} / 250 \mathrm{~mL})$ in a soxhlet extractor for 8 to 10 hours, sequentially with the alcoholic solvents viz., hexane, benzene, chloroform and methanol and water. Then the extracts were evaporated to dryness and stored at $4^{\circ} \mathrm{Cfor}$ further use.

\section{Source of microbial strains}

In vitro antimicrobial activity was examined for the crude extracts of tuber part of the study species against 15 bacterial species which include the Gram positive strains viz., Streptococcus faecalis, S. pyogenes, Bacillus subtilis, B. thuringiensis, Staphylococcus aureus and Enterococcus faecalis and Gram negative strains viz., Klebsiella pneumoniae, Salmonella paratyphi, $S$. 
paratyphi A, S. paratyphi B, Escherichia coli, Proteus vulgaris, $P$. mirabilis, Serratia marcescens and Pseudomonas aeruginosa and 9 fungal species viz; Aspergillus fumigatus, A. niger, Candida albicans, Paecilomyces lilacinus, Trichoderma viride, Verticillium lecanii, Mucor sp., Fusarium sp. and Penicillium sp. All these microbial strains were obtained from the Department of Microbiology, Hindustan College of Arts and Science, Coimbatore. The bacterial and fungal stock cultures were maintained on nutrient and potato dextrose agar slants respectively at $4^{\circ} \mathrm{C}$ and the fungal cultures were maintained on potato dextrose agar medium at $4^{\circ} \mathrm{C}$ for further use.

\section{Antimicrobial assay}

The antimicrobial activities were tested by the disc diffusion method ${ }^{16}$. Each bacterial strain was suspended in nutrient (Mulller-Hinton) broth and each fungal strain was suspended in potato dextrose broth and incubated for $8 \mathrm{~h}$ at $37^{\circ} \mathrm{C}$. Then the inoculum was spread over respective agar medium with sterile glass spreader. Small circular paper discs (5mm diameter) impregnated with known amount of each extract was placed upon the surface of the inoculated plates separately. The plates were kept at room temperature for absorption of extract in the medium and then incubated at $37^{\circ} \mathrm{C}$ in the incubator for 24 to $48 \mathrm{hrs}$. The antimicrobial activity was evaluated by measuring the diameter of inhibition zone ${ }^{17}$. Ampicillin and tetracycline were used as positive control and Dimethyl sulfoxide (DMSO) was used as negative control. Triplicates were maintained for all experiments.

\section{Minimum inhibitory concentration (MIC)}

MIC was determined through the broth dilution method $^{18}$. Microbes were first grown in the respective broths for 24 to $48 \mathrm{hrs}$ and then the inoculums were diluted for five times $\left(10^{-5}\right.$ dilution $)$ because to control its vigorous growth. For the determination of MIC, each test tube with $1800 \mu \mathrm{l}$ of respective broths was added with eight different concentrations of methanolic tuber extracts (100 to $800 \mu \mathrm{g} / \mathrm{mL})$ separately followed by inoculation of $200 \mu \mathrm{l}$ of respective microbes and kept at $37^{\circ} \mathrm{C}$ for $24-48 \mathrm{hrs}$. The tubes were examined for visual turbidity and compared with the respective positive and negative controls.

\section{Statistical analysis}

For in vitro antimicrobial activity of the extracts, the results were recorded as mean \pm standard deviation (SD) $(\mathrm{n}=3)$ and subjected to one-way analysis of variance (ANOVA) followed by post hoc Duncan's multiple range test using SPSS (version 9, SPSS Inc., Chicago, USA). $P<0.05$ was chosen as the criterion for statistical significance.

\section{RESULTS}

\section{Antimicrobial activity}

The antimicrobial activities of $S$. amplexicaulis tuber extracts were assayed in vitro by agar disc diffusion method against 15 bacterial and 9 fungal species. Tables 1 and 2 summarize the microbial growth inhibition of hexane, benzene, chloroform, methanol and water extracts of the study species and their respective standards. Among them, the benzene, chloroform and methanol extracts showed significant activity against all the tested bacterial species which was ranging between 7.0 and $11.7 \mathrm{~mm}, 9.1$ and $28.3 \mathrm{~mm}$, and 6.3 and $12.3 \mathrm{~mm}$ respectively. The inhibitory zone for fungal species which was ranging between 11.3 and $23.1 \mathrm{~mm}, 12.2$ and $27.3 \mathrm{~mm}$, and 9.0 to $14.1 \mathrm{~mm}$ respectively. The methanol extract showed moderate activity but the hexane extract the activity was not noteworthy.

Table 1: Antibacterial activity of the tuber extract of Solena amplexicaulis on certain bacteria.

\begin{tabular}{|c|c|c|c|c|c|c|c|}
\hline \multirow{2}{*}{ S.No } & \multirow{2}{*}{ Name of the bacteria } & \multicolumn{6}{|c|}{ Diameter of inhibition zone (mm) } \\
\hline & & Control* & Hexane & Benzene & Chloroform & Methanol & Water \\
\hline & \multicolumn{7}{|l|}{ Gram Positive Bacteria } \\
\hline 1. & Streptococcus faecalis & $19.2 \pm 0.8^{\mathrm{ab}}$ & - & $7.3 \pm 0.2^{\mathrm{a}}$ & $15.1 \pm 0.3^{b}$ & $6.3 \pm 0.7^{\mathrm{a}}$ & - \\
\hline 2. & S. pyogenes & $21.5 \pm 0.2^{\mathrm{b}}$ & - & $10.5 \pm 0.1^{\mathrm{d}}$ & $18.3 \pm 0.7^{\mathrm{c}}$ & $8.5 \pm 0.1^{\mathrm{ab}}$ & $10.1 \pm 0.6^{\mathrm{b}}$ \\
\hline 3. & Bacillus subtilis & $15.0 \pm 0.2^{\mathrm{a}}$ & - & $7.5 \pm 0.5^{\mathrm{a}}$ & $9.1 \pm 0.8^{\mathrm{a}}$ & $7.1 \pm 0.3^{\mathrm{a}}$ & - \\
\hline 4. & B. thuringiensis & $22.3 \pm 0.6^{\mathrm{b}}$ & - & $9.3 \pm 1.1^{\mathrm{c}}$ & $13.5 \pm 1.3^{\mathrm{ab}}$ & $11.5 \pm 0.2 \mathrm{~d}^{\mathrm{b}}$ & $12.0 \pm 1.0^{\mathrm{c}}$ \\
\hline 5. & Staphylococcus aureus & $15.2 \pm 0.1^{\mathrm{a}}$ & - & $8.3 \pm 0.2^{b}$ & $12.5 \pm 1.7^{\mathrm{ab}}$ & $8.8 \pm 0.6^{\mathrm{ab}}$ & $7.5 \pm 0.8^{\mathrm{a}}$ \\
\hline \multirow[t]{2}{*}{6.} & Enterococcus faecalis & $22.1 \pm 0.4^{\mathrm{b}}$ & - & $11.0 \pm 0.1^{\mathrm{e}}$ & $28.3 \pm 0.8^{\mathrm{d}}$ & $12.3 \pm 0.3^{\mathrm{c}}$ & $8.5 \pm 0.1^{\mathrm{a}}$ \\
\hline & \multicolumn{7}{|l|}{ Gram Negative Bacteria } \\
\hline 7. & Klebsiella pneumonia & $22.1 \pm 1.2^{\mathrm{b}}$ & - & $11.7 \pm 0.6^{\mathrm{e}}$ & $20.1 \pm 0.2^{\mathrm{cd}}$ & $10.3 \pm 0.1^{b}$ & $10.1 \pm 0.7^{b}$ \\
\hline 8. & Salmonella paratyphi & $27.2 \pm 1.5^{\mathrm{d}}$ & - & $7.5 \pm 0.3^{\mathrm{a}}$ & $13.2 \pm 0.5^{\mathrm{ab}}$ & $8.1 \pm 0.7^{\mathrm{ab}}$ & $10.3 \pm 0.1^{b}$ \\
\hline 9. & S. paratyphi A & $14.5 \pm 0.1^{\mathrm{a}}$ & - & $11.3 \pm 0.4^{\mathrm{e}}$ & $10.1 \pm 0.8^{\mathrm{a}}$ & $10.5 \pm 0.2^{b}$ & $8.5 \pm 0.6^{\mathrm{a}}$ \\
\hline 10. & S. paratyphi B & $25.0 \pm 0.9^{c}$ & $7.3 \pm 0.3^{\mathrm{a}}$ & $10.7 \pm 0.5^{\mathrm{d}}$ & $23.3 \pm 0.1^{\mathrm{cd}}$ & $13.3 \pm 0.4^{\mathrm{c}}$ & $12.5 \pm 0.1^{\mathrm{c}}$ \\
\hline 11. & Escherichia coli & $21.1 \pm 0.5^{\mathrm{b}}$ & - & $8.5 \pm 1.7^{b}$ & $18.0 \pm 1.2^{\mathrm{c}}$ & $10.0 \pm 0.3^{b}$ & $11.3 \pm 1.1^{\mathrm{c}}$ \\
\hline 12. & Proteus vulgais & $15.1 \pm 0.3^{\mathrm{a}}$ & - & $7.0 \pm 0.3^{\mathrm{a}}$ & $10.3 \pm 1.0^{\mathrm{a}}$ & $8.5 \pm 0.2^{\mathrm{ab}}$ & - \\
\hline 13. & P. mirabilis & $17.2 \pm 1.3^{\mathrm{ab}}$ & - & $7.3 \pm 0.5^{\mathrm{a}}$ & $9.5 \pm 1.1^{\mathrm{a}}$ & $8.3 \pm 0.7^{\mathrm{ab}}$ & - \\
\hline 14. & Serratia marcescens & $23.4 \pm 1.8^{\mathrm{c}}$ & - & $7.5 \pm 0.3^{\mathrm{a}}$ & $18.3 \pm 0.8^{\mathrm{c}}$ & $9.5 \pm 0.3^{b}$ & $8.3 \pm 0.7^{\mathrm{a}}$ \\
\hline 15. & $\begin{array}{l}\text { Pseudomonas } \\
\text { aeruginosa }\end{array}$ & $23.7 \pm 0.5^{\mathrm{c}}$ & - & $7.1 \pm 1.3^{\mathrm{a}}$ & $20.4 \pm 0.3^{\mathrm{cd}}$ & $12.0 \pm 0.8^{\mathrm{c}}$ & $14.2 \pm 0.9^{\mathrm{d}}$ \\
\hline
\end{tabular}

Values are expressed as mean $\pm S D$ of three parallel measurements.

Means followed by different letter(s) in columns are significant to each other at 5\% level according to DMRT.

*Ampicillin 
Among the five solvent extracts attempted, the chloroform extract showed higher inhibitory activity $(28.3 \mathrm{~mm})$ against the bacterium, Enterococcus faecalis which was significantly higher than the zone of inhibition caused by the standard drug, Ampicillin $(22.1 \mathrm{~mm})$. However this extract showed very less inhibitory effect against the bacterium, Bacillus subtilis $(9.1 \mathrm{~mm})$. The negative control (DMSO) did not produce zone of inhibition. The tuber extract effectively inhibited the growth of both Gram positive and Gram negative bacteria. The fungal strains were also highly sensitive to the chloroform extract which include Candida albicans (27.5mm), Mucor sp. (27.3mm) and Trichoderma viride $(22.0 \mathrm{~mm})$. From these results, it is known that the chloroform extract of $S$. amplexicaulis tuber exhibited broad spectrum of antimicrobial activity.

Table 2: Antifungal activity of the tuber extract of Solena amplexicaulis on certain fungi

\begin{tabular}{|c|c|c|c|c|c|c|c|c|c|}
\hline \multirow{2}{*}{$\begin{array}{c}\text { Plant } \\
\text { extracts }\end{array}$} & \multicolumn{7}{|c|}{ Diameter of inhibition zone (mm) } \\
\cline { 2 - 9 } & AF & AN & CA & PL & TV & VL & M sp. & F sp. & P sp. \\
\hline Control & $47.0 \pm 1.3^{\mathrm{c}}$ & $27.5 \pm 1.7^{\mathrm{a}}$ & $42.3 \pm 1.9^{\mathrm{b}}$ & $45.0 \pm 0.3^{\mathrm{c}}$ & $42.5 \pm 1.2^{\mathrm{b}}$ & $41.1 \pm 0.4^{\mathrm{b}}$ & $46.0 \pm 1.8^{\mathrm{c}}$ & $41.3 \pm 0.5^{\mathrm{b}}$ & $43.0 \pm 1.8^{\mathrm{bc}}$ \\
\hline Hexane & - & - & - & $7.3 \pm 1.2^{\mathrm{a}}$ & - & - & - & $18.1 \pm 1.2^{\mathrm{b}}$ & - \\
\hline Benzene & $17.3 \pm 0.3^{\mathrm{b}}$ & $10.2 \pm 0.2^{\mathrm{a}}$ & $11.8 \pm 0.7^{\mathrm{a}}$ & $23.1 \pm 1.5^{\mathrm{c}}$ & $15.2 \pm 1.5^{\mathrm{b}}$ & $11.3 \pm 0.5^{\mathrm{a}}$ & $16.1 \pm 0.9^{\mathrm{b}}$ & $20.5 \pm 0.5^{\mathrm{bc}}$ & $17.3 \pm 0.1^{\mathrm{b}}$ \\
\hline Chloroform & $25.3 \pm 0.8^{\mathrm{d}}$ & $12.2 \pm 0.3^{\mathrm{a}}$ & $27.5 \pm 0.5^{\mathrm{e}}$ & $15.2 \pm 0.3^{\mathrm{b}}$ & $22.0 \pm 0.2^{\mathrm{c}}$ & $17.2 \pm 0.8^{\mathrm{bc}}$ & $27.3 \pm 1.7^{\mathrm{e}}$ & $14.2 \pm 0.4^{\mathrm{ab}}$ & $25.1 \pm 1.3^{\mathrm{d}}$ \\
\hline Methanol & $10.0 \pm 0.1^{\mathrm{ab}}$ & $7.5 \pm 1.3^{\mathrm{a}}$ & $9.5 \pm 1.5^{\mathrm{ab}}$ & $14.1 \pm 0.2^{\mathrm{b}}$ & $8.5 \pm 1.8^{\mathrm{a}}$ & $10.3 \pm 0.9^{\mathrm{ab}}$ & $9.0 \pm 0.3^{\mathrm{ab}}$ & $11.2 \pm 0.7^{\mathrm{b}}$ & $10.2 \pm 1.0^{\mathrm{ab}}$ \\
\hline Water & $6.3 \pm 1.5^{\mathrm{a}}$ & $6.8 \pm 0.8^{\mathrm{a}}$ & $9.3 \pm 0.5^{\mathrm{d}}$ & - & - & $7.1 \pm 0.2^{\mathrm{b}}$ & $8.2 \pm 0.5^{\mathrm{c}}$ & $7.5 \pm 0.7^{\mathrm{b}}$ & $6.3 \pm 0.6^{\mathrm{a}}$ \\
\hline
\end{tabular}

Values are expressed as mean $\pm S D$ of three parallel measurements.

Means followed by different letter(s) in columns are significant to each other at 5\% level according to DMRT.

*Tetracycline, AF-Aspergillus fumigatus, AN-A. niger, CA-Candida albicans, PL-Paecilomyces lilacinus, TV-Trichoderma viride,

VL-Verticillium lecanii, M sp.-Mucor sp., F sp.-Fusarium sp. and P sp.-Penicillium sp.

\section{Minimum Inhibitory Concentration (MIC)}

MIC was defined as the lowest concentration of the extract inhibiting the visible growth of each microorganism ${ }^{19}$. Yield-wise, other solvent extracts except methanolic extract showed poor response. Hence
MIC was determined only for the methanolic extract (Table 3 and 4). The MIC values are ranging between 300 and $600 \mu \mathrm{g} / \mathrm{mL}$ for bacterial species and 300 and $500 \mu \mathrm{g} / \mathrm{mL}$ for fungal species. When compared to the fungal strains the bacterial strains were highly resistant to this tuber extract.

Table 3: Minimum inhibitory concentration (MIC) of methanolic extract of tuber part of Solena amplexicaulis on certain pathogenic bacteria

\begin{tabular}{|c|c|c|c|c|c|c|c|c|c|c|c|c|c|c|c|}
\hline \multirow{3}{*}{ Plant Part } & \multicolumn{15}{|c|}{ Minimum Inhibitory Concentration $(\mu \mathrm{g} / \mathrm{mL})$} \\
\hline & \multicolumn{6}{|c|}{ Gram positive bacteria } & \multicolumn{9}{|c|}{ Gram negative bacteria } \\
\hline & $\mathrm{SF}$ & SP1 & BS & BT & SA & EF & KP & SP2 & SP3 & SP4 & EC & PV & PM & SM & PA \\
\hline Tuber & 600 & 500 & 500 & 300 & 500 & 300 & 400 & 500 & 400 & 300 & 400 & 500 & 500 & 500 & 300 \\
\hline
\end{tabular}

SF-Streptococcus faecalis, SP1 - S. pyogenes, BS - Bacillus subtilis, BT - B. thuringiensis, SA - Staphylococcus aureus, EF Enterococcus faecalis, KP - Klebsiella pneumoniae, SP2 - Salmonella paratyphi, SP3 - S. paratyphi A, SP4 - S. paratyphi B, EC Escherichia coli, PV - Proteus vulgaris, PM - P. mirabilis, SM - Serratia marcescens and PA - Pseudomonas aeruginosa.

Table 4: Minimum inhibitory concentration (MIC) of methanolic extract of tuber part of Solena amplexicaulis on certain pathogenic fungi

\begin{tabular}{|c|c|c|c|c|c|c|c|c|c|}
\hline \multirow{2}{*}{$\begin{array}{c}\text { Plant } \\
\text { Part }\end{array}$} & \multicolumn{8}{|c|}{ Minimum Inhibitory Concentration $(\mu \mathrm{g} / \mathrm{mL})$} \\
\cline { 2 - 10 } & AF & AN & CA & PL & TV & VL & M sp. & F sp. & P sp. \\
\hline Tuber & 300 & 500 & 400 & 300 & 500 & 300 & 400 & 300 & 300 \\
\hline
\end{tabular}

AF-Aspergillus fumigatus, AN-A. niger, CA-Candida albicans, PL-Paecilomyces lilacinus, TV-Trichoderma viride, VL-Verticillium lecanii, M sp.-Mucor sp., F sp.-Fusarium sp. and P sp.-Penicillium sp.

\section{DISCUSSION}

The antimicrobial studies revealed that all the extracts of the tuber part of $S$. amplexicaulis have inhibitory effects at varying degrees against the growth of bacteria and fungi tested (Tables 1and 2). As S. ampliexicaulis has mainly distributed in dry deciduous forests, the water stress may induce the plant to produce large variety of secondary metabolites for its defense mechanism ${ }^{20,21}$. (C) 2011-14, JDDT. All Rights Reserved
The basis of varying degree of sensitivity of test organisms may be due to the intrinsic tolerance of microorganisms and the nature and combinations of phytochemical compounds present in the crude extract. The chloroform extract showed highest inhibitory activity (inhibitory zone -9 to $28 \mathrm{~mm}$ ) than that of the other extracts. The zone of inhibition, $\geq 9-15 \mathrm{~mm}$ is an indication of the existence of strong antimicrobial 
activity $^{22}$. Different solvents have been reported to have different capacity to extract phytoconstituents according to their solubility or polarity ${ }^{23}$. Many studies are supporting that chloroform extract of several medicinal plant species are having higher antibacterial activities than that of any other alcoholic solvents ${ }^{24,25}$. Generally the Cucurbitaceae family contains more amount of bioactive compounds viz., cucurbitacin, triterpenes, sterols and alkaloids ${ }^{26}$ and also many early studies reported that the member of Cucurbitaceae showed more pronounced antimicrobial activity ${ }^{27,28,29}$. This may be attributed to the presence of various bioactive compounds in the tuber which may have the capacity to rupture the cytoplasmic membrane of the microbial cells and damage the intercellular compounds ${ }^{30}$ or they may interact the lipid bilayer or inhibit the protein and nucleic acid synthesis of the microbial cells ${ }^{31}$. In comparison to that of other extracts the hexane extract did not show much activity. It is of common fact that the low polar solvents didn't extract more types of phytochemical compounds ${ }^{32}$. The bacterium, Enterococcus faecaulis and the fungi, Candida albicans, Mucor sp. and Trichoderma viride were determined to be highly sensitive to chloroform extract of Solena amplexicaulis tuber. These microorganisms are causing life threatening infections to humans ${ }^{33}$. The MIC values of methanolic extracts are represented in Tables 3 and 4. The MIC values were ranging between 300 and $600 \mu \mathrm{g} / \mathrm{mL}$ for bacterial species and 300 and $500 \mu \mathrm{g} / \mathrm{mL}$ for fungal species. Available information through

\section{REFERENCES}

1. WHO 'Burden of disease and cost effectiveness estimates', [http://www.who.int/water_sanitation_health/diseases/burden/ en/]

2. Shariff ZU, Modern Herbal Therapy for Common Ailments. Nature Pharmacy Series. (Vol 1). Spectrum Books Limited, Ibadan, Nigeria in Association with Safari Books (Export) Limited, UK: 2001. P. 9-84.

3. Rivera JO, Loya AM, Ceballos R, Use of herbal medicines and implications for conventional drug therapy medical sciences, Alternative and integrative medicine, 2013, 2(6): 130 .

4. Oliveira AA, Segovia JFO, Sousa VYK, Mata ECG, Gonealves MCA, Bezerra RM, Junior POM, Kanzaki LIB, Antimicrobial activity of Amazonian medicinal plants. Springer Plus. 2013, 2, 371.

5. Sharma $\mathrm{BC}$, In vitro antibacterial activity of certain folk medicinal plants from Darjeeling Himalayas used to treat microbial infection, Journal of Pharmacognosy and Phytochemistry, 2013, 2(4), 1-4.

6. Kritchevsky D, Fiber, lipids and atherosclerosis, American Journal of Clinical Nutrition, 1978, 31S, 65-74.

7. Dhananjay J. Deshpande, A hand book of medicinal herbs, Agrobios, Jodhpur, India. 2006, 325-327.

8. Venkateshwaralu E, Raghuram Reddy A, Goverdhan P, Swapna Rani K, Jayapal Reddy G. In vitro and in vivo antioxidant activity of methanolic extract of Solena amplexicaulis (whole plant). International Journal of Pharma Bio Science, 2011,1(4), 522-533.

9. Karthika K, Paulsamy S, Jamuna S, Evaluation of in vitro antioxidant potential of methanolic leaf and stem extracts of Solena amplexicaulis (Lam.) Gandhi., Journal of Chemical and Pharmaceutical Research, 2012,4(6), 3254-3258.

10. Pullaiah T, Murthy KSR, Goud PSP, Kumar TDC, Vijayakumar R, Medicinal plants used by the tribals of Nallamalais, Eastern Ghats of India, Journal of Tropical Medicinal Plants, 2003, 4(2), 237-244. literature showed that MIC values between $50-500 \mu \mathrm{g} / \mathrm{mL}$ exhibit strong activity $600-1500 \mu \mathrm{g} / \mathrm{mL}$ exhibit moderate activity and above $1500 \mu \mathrm{g} / \mathrm{mL}$ exhibit poor activity ${ }^{34}$. Based on the performance, it is known that the tuber extract of S. amplexicaulis may be a solution for infectious diseases. Further, it was observed that susceptibility increased with the increase in concentration of the extracts. However, the present study on in vitro antimicrobial evaluation of $S$. amplexicaulis forms a primary platform for further phytochemical and pharmacological studies, in this species.

\section{CONCLUSION}

The present findings support the applicability of $S$. amplexicaulis in traditional system for its claimed uses and can be recommended by the scientific community as an accessible alternative to synthetic antibiotics. The high degree of antimicrobial activity seems to support the folk therapy for infections and traditional therapeutic claims of this plant.

\section{ACKNOWLEDGMENTS}

The authors graciously acknowledge the financial support given by University Grants Commission, New Delhi (Grant No. F. 41-415/2012(SR)) to carry out the work

\section{CONFLICTS OF INTEREST}

We declare that we have no conflicts of interest.

11. Karthika K, Paulsamy S, Antibacterial potential of traditional plant species Solena amplexicaulis (Lam.) Gandhi. against certain human pathogens, Asian Journal of Pharmaceutical and Clinical Research, 2012, 5(Suppl 4), 255-257.

12. Arun Ch, Satheesh Kumar R, Srinu S, Lal Babu G, Raghavendra Kumar G, Amos Babu J, Antiinflammatory activity of aqueous extract of leaves of Solena amplexicaulis, International Journal of Research in Pharmaceutical and Biomedical Sciences, 2011, 2(4), 1617-1619.

13. Mohammed R, Paritosh C, Alok Kumar P, Dilruba N, Rasheda A, Farhana J, Dilara F, Mira A, Nusratun N, Shamima A, Rownak J, A survey of preventive medicinal plants used by the Chakma residents of Hatimara (south) village of Rangamati district, Bangladesh, American Eurasian Journal of Sustainable Agriculture, 2011, 5(1), 9296.

14. Jeyaprakash K, Ayyanar M, Geetha KN, Sekar T, Traditional uses of medicinal plants among the tribal people in Theni District (Western Ghats), Southern India, Asian Pacific Journal of Tropical Biomedicine, 2011, 1(1), S20-S25.

15. Abdolbaset G, Gerhard L, Liu F, Joachim S, Ethnobotanical study of medicinal plants utilised by Hani ethnicity in Naban River Watershed National Nature Reserve, Yunnan, China, Journal of Ethnopharmacology, 2011, 134(3), 651-667.

16. Bauer RW, Kirby MDK, Sherris JC, Turek M, Antibiotic susceptibility testing by standard single disc diffusion method, American Journal of Clinical Pathology, 1966, 45, 493-496

17. Kim J, Marshall MR, Wei C, Antibacterial activity of some essential oil components against five food borne pathogens, Journal of Agricultural and Food Chemistry, 1995, 43, 28392845 .

18. Koneman EW, Allen SD, Janda WN, Schreckenberger PC, Winn WC, The "family Streptococcaceae": taxonomy and clinical significance. Color atlas and textbook of diagnostic 
microbiology, 5th ed. Pa: Lippincott: Williams and Wilkins Publishers; Philadelphia, 1997, P. 581.

19. Vipra A, Desai SN, Junjappa RP, Roy P, Poonacha N, Ravinder P, Sriram B, Padmanabhan S, Determining the Minimum Inhibitory Concentration of Bacteriophages: Potential Advantages, Advances in Microbiology, 2013, 3, 181-190.

20. Sahoo KP, Kasera PK, Mohammed S, Secondary metabolites produced during different seasons in some arid medicinal plant, Asian Journal of Plant Science and Research, 2012, 2(6), 650-652.

21. Loreto F, Schnitzler JP, A biotic stresses and induced biogenic volatile organic compounds, Trends in Plant Science, 2010, 15, 154-166.

22. Rani O, Khullar N, Antimicrobial evaluation of some medicinal plants for their anti-enteric potential against multi drug resistant Salmonella typhi, Phytotherapy Research, 2004, $18,670-673$.

23. Marjorie MC, Plant product as antimicrobial agents, Clinical Microbiology Reviews, 1999, 12, 564-582.

24. Ashraf Z, Muhammad A, Imran M, Tareq A.H, In vitro antibacterial and antifungal activity of methanol, chloroform and aqueous extracts of Origanum vulgare and their comparative analysis, International Journal of Organic Chemistry, 2011, 1, 257-261.

25. Singariya P, Mourya KK, Padma K, Antimicrobial activity of the crude extracts of Withania somnifera and Cenchrus setigerus in - vitro, Pharmacognosy Journal, 2012, 4(27), 6065.

26. Achu MB, Fokou E, Tchiegang C, Fotso M, Tchouanguep FM, Nutritive value of some Cucurbitaceae oil seeds from different regions in Cameroon, African Journal of Biotechnology, 2005, 4(11), 1329-1334.

27. Patel E, Krishnamurthy R, A review on potency of some Cucurbitaceae plants against hepatitis and antimicrobial activities, Indian Journal of Fundamental and Applied Life Sciences, 2013, 3(2), 13-18.

28. Bolay B, Monisankar S, Pinaki P, Subrata C, Amalesh S, In vitro evaluation of antifungal and antibacterial activity of the plant Coccinia grandis (L.) Voigt. (Family. Cucurbitaceae), Journal of Phytology, 2010, 2(11), 52-57.

29. Sangeetha S, Chetana SH, Padmaa MP, Vedamurthy AB, Antimicrobial activity of Momordica cymbalaria Fenzl. aerial parts extracts, Indian Journal of Natural Products and Resources, 2010, 1(3), 296-300.

30. Chen HM, Chan SC, Lee JC, Chang CC, Murugan M, Jack $\mathrm{RJ}$, Transmission electron microscopic observations of membrane effects of antibiotic cecropin B on Escherichia coli, Microscopy Research and Technique, 2003, 62, 423-430.

31. Adetumbe A, Javor GT, Lau BH, Allium Sativum (garlic) inhibits lipid synthesis by Candida albicans, Antimicrobial Agents and Chemotheraphy, 1986, 30(3), 499-501.

32. Duraipandiyan V, Ignacimuthu $\mathrm{S}$, Antifungal activity of traditional medicinal plants from Tamil Nadu, India, Asian Pacific Journal of Tropical Biomedicine, 2011, S204-S215.

33. Rocas IN, Siquiera JF, Santos KR, Association of Enterococcus faecalis with different forms of periradicular diseases, Journal of Endodontics, 2004, 30(5), 315-320.

34. Murat TY, Minimum inhibitory and minimum bactericidal concentrations of boron compounds against several bacterial strains, Turkish Journal of Medical Sciences, 2012, 42 (Sup 2), 1423-1429. 